\title{
South African defence in the age of total war, 1900-1940
}

\author{
Ian van der Waag
}

\section{Introduction}

In November 1941, South Africa suffered a crushing blow. The same month that her forces had mopped up a motley crew of Italians in East Africa, they suddenly had to face a resolute German army in North Africa under the formidable Erwin Rommel. During fierce fighting on 22 and 23 November, the 5th SA Infantry Brigade was overrun and annihilated by a German armoured assault at Sidi Rezegh, a battle described as the largest and most violent tank battle of the North African campaign. Rommel counterattacked and outflanked the Allied forces from the west. At 7:30 a.m. on the morning of November 22 his panzers knifed through the brigade, cutting it off from the rest of the 7 th UK Armoured Division. The carnage was terrible. The Brigade had gone into battle 5700 strong; when the survivors assembled at Mersa Matruh only 2306 were left. Over 600 were killed or wounded and the rest had been captured. $^{1}$

Such "lessons" are often cast dramatically by "first battles", a term adopted by Charles E. Heller and William A. Stofft to explain that first engagement in a war when the strengths and weaknesses of an army's peacetime preparation, doctrinal development and force design, as well as the mobilisation for the war itself, are tested by the exigencies of conflict and are found either to be good or in demand of urgent, wartime adjustment. ${ }^{2}$ Sidi Rezegh was, in many ways, a first-battle experience for the Union Defence Force. The "lessons" were expensive and highlight poor peace-time planning and preparation, and a military leadership affected by little training and no real experience, issues addressed in a report on

lan van der Waag, MA (Pretoria), PhD (Cape Town), is associate professor and head of the Department of Military History in the Faculty of Military Science, University of Stellenbosch. This article is a revision of a paper presented at the "Small States in the Age of Total War" conference hosted by the Royal Military Academy, Breda, The Netherlands, 26-27 November 2008, for which he is delighted to thank professors Herman Amersfoort and Wim Klinkert. He is also most happy to acknowledge the insights offered by Lt Col (Prof.) Deon Visser as well as the two anonymous referees. Lt Evert Kleynhans and Mr Will Gordon are thanked for the Afrikaans abstract.

How to cite this article:

Van der Waag I. South African defence in the age of total war, 1900-1940. Historia. 2015; 1(1), Art. 26 pages.

http://dx.doi.org/10.17159/2309-8392/2015/v60n1a8

1. The rout was considered largely the fault of the 5th Brigade's staff. Major General W.H.E. Gott, commander of the 7th Armoured Division remarked to a South African armour officer (Lt Col V. Larmuth) shortly before the German assault: "Your South African Brigade seems stuck down with gum - they won't move and they won't turn their artillery round and they are not dug in - I am sorry for them." Larmuth, quoting Gott, see J.A.I. Agar-Hamilton and L.C.F. Turner, The Sidi Rezeg Battles 1941 (Oxford University Press, Cape Town, 1957), p 249. For an incisive, recent study see D. Katz, "Sidi Rezegh and Tobruk; Two South African Military Disasters Revisisted, 1941-1942", MMil thesis, Stellenbosch University, 2014.

2. C.E. Heller and W.A. Stofft (eds), America's First Battles, 1776-1965 (University Press of Kansas, Lawrence 1986), pp ix-X. 
the military position in South Africa on 7 September 1939. The circumstances sketched in this report were the result of long term neglect, the gradual whittling away of military intellect and real military leadership, and the appointment of managers and the politically-willing, who push messages rather than getting to grips with strategy, military theory, military history and other time-consuming, challenging pursuits. ${ }^{3}$ But then South Africa was not unique in this respect. Armed forces around the globe failed to innovate because, as Williamson Murray has noted, the interwar years were marked by stringent military budgets and a distrust of military institutions, which were confronted simultaneously by a range of technological, tactical, operational and strategic challenges, and all were moreover clouded by the murky "lessons" of the First World War. ${ }^{4}$

This paper aims to do three things essentially. ${ }^{5}$ It will attempt firstly, to sketch, in broad brush strokes the political-strategic framework within which the Union Defence Force and its predecessors had to function between 1900 and 1940. Secondly, the organisational and extraneous factors that affected the functioning and influenced the preparations of the Union Defence Forces will be set out. Thirdly, the doctrinal framework, including an assessment of the services' commitment to the problem of doctrine and of their rigour in drawing, learning and implementing the so-called "lessons" of the First World War, will be explored. It will therefore address the South African reaction to the brutality and high costs of industrialised warfare and explain the attempts, apparently always feeble, by the South African state to adapt to the changing face of modern warfare. It will also address the matter of force design and attempt to answer the question of why the Union Defence Force, after the experience at Delville Wood (July 1916) especially, was still so unprepared for European warfare in 1941.

\section{South Africa's politico-strategic environment}

Any investigation of the causes for the poor military condition in 1939 goes back to the turn of the century, when South Africa was still a geographic expression for an assortment of British colonies, former Boer republics and a number of recentlyconquered African kingdoms and chiefdoms. The ending of the Second Anglo-Boer War (1899-1902) ushered in a new era for southern Africa, one of undoubted British supremacy. Yet Pax Britannica was no panacea for a troubled region. Several strategic problems, some of which were new, vexed. The worst, but least likely contingency, never constant and seldom real, was a war between Britain and an imperial power and particularly one opposing Britain in Africa. If the enemy was Germany or Portugal, the war would probably include an overland invasion from South West Africa (Namibia) or Mozambique, the firing of an Afrikaner rebellion and, in the case of Germany, a limited naval campaign in the Southern Oceans. A war with France or Belgium would involve the same problems less the landward invasion, but with the possible addition of an African rising. South Africa differed from the

3. National Archives of South Africa, Pretoria (hereafter NASAP): A.1, Field Marshal J.C. Smuts Papers, vol. 132, "Statement of the Local Military Position on 7 September 1939 and steps taken thereafter".

4. W. Murray, "Armoured Warfare: The British, French, and German Experiences", in W. Murray and A.R. Millett, Military Innovation in the Interwar Period (Cambridge University Press, Cambridge, 1998), p 8.

5 This framework is suggested by Murray and Millett, Military Innovation in the Interwar Period, pp 1-5. 
other self-governing dominions, for she had European powers within marching distant of her land boundaries and with easy access to her ports. The Royal Navy presence at Simonstown, a second-class naval base, was both a consolation as well as a political conundrum. ${ }^{6}$

Plans were drawn up by the imperial authorities and the colonial administrations in the four British colonies in South Africa to counter the eventualities; they were coded alphabetically, Plan $Z$ being a lightning strike against the Portuguese in Lourenço Marques. ${ }^{7}$ Yet, except for minor operations within the borders of British South Africa, ${ }^{8}$ the imperial defence authorities knew they did not have sufficient troops and so, from 1902 until 1912, they turned their attention to the creation of a manpower mobilisation system that reconciled projected wartime force estimates with the often whimsical, seldom extravagant notions of British imperial and South African politicians, administrators and officials.

The answer was found momentarily in finding a balance between the declining number of imperial troops and the fostering of volunteer organisations in the colonies. A fundamental overhauling of military policy, it was hoped, would create a geography of loyalism on the Highveld. ${ }^{9}$ British settlers, encouraged by rumoured native risings, rushed to the colours. The Boers, defeated in 1902 and disarmed briefly, were courted and encouraged and many enlisted, although they joined the British-style volunteer regiments for reasons of rural insecurity rather than any feeling of loyalty to the British crown. Although momentarily mollified by the promise of better rural security, Afrikaner republicans vacated the volunteer regiments from 1907 and enlisted in the resurrected commandos.

The Zulu rebellion that erupted in Natal in 1906, which bears Bhambatha's name, highlighted several weaknesses in colonial defence planning and so sparked military co-operation and furthered military thinking. ${ }^{10}$ Spurred on by the initial successes achieved by Bhambatha, the troops in South Africa, both imperial and colonial, underwent training in asymmetrical warfare. A pamphlet on Savage Warfare, written by Colonel (later Major General Sir) H.T. Lukin and published in May $1906,{ }^{11}$ was studied and practised in the field, although not without some

6. Military Archives, SANDF Documentation Centre, Pretoria: Diverse, Box 15, file 199, Colonial Defence Committee Memoranda on General Defence Matters, Bourne to Smuts, 8 September 1910; and Smuts to Bourne, 20 September 1910.

7. SANDF Documentation Centre, Pretoria: Archives of the Secretary for Defence (hereafter DC), Box 356, DC40057, Intelligence Section Secret report from Major J.G.W. Leipoldt to the Adjutant General, 22 December 1917. See also SADF Documentation Centre: Union War Histories, Box 339, Miss Pope-Hennessy, "Z Plan Narrative", 1949.

8. These were the colonies of the Cape of Good Hope and of Natal as well as the two former Boer republics that had been incorporated into the British Empire in 1900 as the Transvaal Colony and the Orange River Colony.

9. The term "geography of loyalism" is adopted from K. Linch, "A Geography of Loyalism? The Local Military Forces of the West Riding of Yorkshire, 1794-1814", War \& Society, 19, 1, May 2001, p 2.

10. See, for example, Lt Col H.A. Wyndham, "Some Aspects of South African Defence", The State, 2, 6, June 1909; and Major P.A. Silburn, The Colonies and Imperial Defence (Longmans, London, 1909).

11. H.T. Lukin, Savage Warfare: Hints on Tactics to be Adopted and Precautions to be Taken (Cape Times Ltd, Cape Town, 1906). See also National Archives of South Africa, Cape 
opposition. The commander of the Southern Mounted Rifles, who may well have preferred a breastplate in the Life Guards, complained of the "dullness" of savagewarfare practices. ${ }^{12}$ Nonetheless, the colonial defence authorities reconsidered the adequacy of their organisations and training and the first steps were taken leading to the reduction of overlapping, the facilitation of co-operation and economy, and leading perhaps to a situation where the imperial government might even "have a call on some proportion" of the force in the case of an international emergency. ${ }^{13}$

South Africa's military forces, at the start of our period colonial and varied, existed between 1900 and 1939 on a political landscape that was apt to change rapidly and dramatically. Several, interrelated factors shaped this environment. First and foremost, was the military geography of South Africa and her relatively isolated position at the southern end of the African continent, seemingly distant from the discord of Europe and Asia. Moreover, South Africans presumed that in the event of war, the enemy would be distant from the bases of his supply and that the Royal Navy, with a base at Simonstown until 1955, would counter any seaborne threat, while the British Army command, in Cape Town until 1921, would assist local forces in repelling a land-based enemy that would, in any case, have to cross difficult country, a vast desert in the west and malarial jungle in the east. South Africa had at this point in Britain and her Empire not simply an ally, but a professed protector that was then the world superpower.

Second, South Africa had her own fault-lines, which were immediately susceptible to the grinding of geopolitical fault-lines in Europe. ${ }^{14}$ The presence of a German colonial army in Namibia and warmth between them and a significant number of Afrikaners, cast this into dramatic relief. There was an almost natural gravitation of Afrikaners, particularly the nationalists of the former republics, to these Germans, who were more alike in stock and had assisted the Boer republics in their war against the British Empire. This had been a total war, one that cast long, historical shadows, and, although the military conflict ended in 1902, for many Afrikaners, brought unwillingly into the British fold, their struggle against "the English" ended only in 1961 when South Africa withdrew from the British Commonwealth of Nations. ${ }^{15}$ In 1914, Britain's claim to protect small nations seemed dubious to many South Africans. Moreover, from 1902, the likelihood of an international war between the great powers was increasing. Imperial rivalries around the world, particularly in Africa and the competition for resources necessary to fuel European industry and manufacture the weapons of industrialised warfare, threatened to make the next war both global and expensive. The shifting of European tectonic plates impacted on South Africa, despite her relative geographic isolation and apparent strategic safety.

Town (hereafter NASAC): CO 8310, file X5114, "Savage Warfare"; P. Truter to Col Lukin, 10 May 1906.

12. West Sussex Record Office (hereafter WSRO): Petworth House Archives (hereafter PHA), uncatalogued letters of H.A. Wyndham, Lt Col Hon Hugh Wyndham to Lady Leconfield, 27 August 1906.

13. Milner to Colonel Charles Crewe, 27 April 1904, in C. Headlam (ed.), Milner Papers: South Africa, Volume 2, 1899-1905 (Cassell \& Co, London, 1933), p 508.

14. N. Ferguson, The War of the World; History's Age of Hatred (Penguin, London, 2007), chapter 3.

15. O. Geyser, Watershed for South Africa, London 1961 (Butterworths, Durban and Pretoria 1983). 
Third, was an almost constant antimilitary sentiment, particularly though not exclusively among Afrikaners, who remained for much of the twentieth century distrustful of the British and of British institutions and baulked at the military institutions the British created. Many Britons misread the situation quite entirely; "the backveld Boer", Maud Wyndham informed her father, "likes to sit on his stoep in safety \& see the English soldiers standing guard \& buying their produce". ${ }^{16}$ But this was an antimilitarism of a peculiarly anti-British nature that permeated the collective mind of a people fashioned by the traditions of small wars and irregular commandos and determined to regain lost independence. Afrikaner domination of the South African political establishment virtually ensured that compulsory peacetime military training, along British lines at least, would not be adopted. Olive Schreiner, the writer of The Story of an African Farm, well-captures the geographic consideration and antimilitarism:

\begin{abstract}
'I seem to have lived in a bath of human blood ever since I can remember! The only thing we need such a defense (sic) force for, is to kill other South Africans. Our position, the nature of our country, the distance from its real base of supplies of any attacking country - even Germany - makes us perfectly safe if we are united. ${ }^{17}$
\end{abstract}

However, this unity as South Africans depended on the development of a local, South African nationalism, something seemingly undermined by the "British connection", which constitutes a third factor. Knowing how tenuous their hold on South Africa was after 1902 and recognising the potential for future challenge, the British courted the Afrikaners, granting self-government within the empire to the former Boer republics and then, encouraged by economic and defence considerations, facilitated the political union in 1910 of the four colonies of the Cape, Natal, Transvaal and Orange River. The Union of South Africa came into being on 31 May 1910 and the Afrikaners, lead by Louis Botha and Jan Smuts, swept to power that September, winning a majority of seats in an election that was disposed towards the rural constituencies. The Unionists, the British oriented party, were only strong on the Witwatersrand and in the large cities of the Cape Province. Natal went to local independents. The forging of a new South African society was built on a consensus that the sectarian interests of the English and Afrikaans communities had to be finely balanced, and the "happiness" of their subject peoples carefully managed. ${ }^{18}$

Military necessity had encouraged political union. The threat of native risings, and the Bhambatha revolt in Natal in 1906, had first led to defence talks between the staffs of the four colonies. Bhambatha, although suppressed easily, revealed all the flaws of South African colonial defence policy and the institutional weaknesses of the colonial militias. Greater inter-colonial military cooperation had followed and after a sequence of military conferences a platform for the creation of

16. Hagley Hall Archives (hereafter HHA): 2/34/13, Maud Wyndham to Lord Cobham, 19 February 1912.

17. University of Cape Town Libraries, Archives and Manuscripts (hereafter UCT): BC294, Duncan Collection, D1.33.2, Olive Schreiner to Patrick Duncan, 27 June 1912.

18. J. Lambert, "South African British? Or Dominion South Africans? The Evolution of an Identity in the 1910s and 1920s", South African Historical Journal, 43, November 2000, especially p 197; J. Lambert, 'An Identity Threatened: White English-speaking South Africans, Britishness and Domestic South Africanism, 1934-1939", Kleio, 37, 2005, p 59. 
a regional military force, which became the Union Defence Forces in July 1912, was established. ${ }^{19}$

But the creation of the Union Defence Forces (UDF) was no easy matter. Jan Smuts, an eager defence minister, had to move cautiously to avoid any "appearance of compulsion or militarism on the European model". ${ }^{20}$ M.T. Steyn, the former president of the Orange Free State, for example, remained concerned that the new force, and the school cadet system especially, would create a spirit of militarism and that the lines between the imperial forces and the Union forces would be blurred. The Afrikaners were not alone. John X. Merriman, Cape politician and elder statesman, was concerned that South Africa "not be led into militarism and to any unwise pledges of sharing in the quarrels in [the] inciting [of] which we have not been consulted". ${ }^{21}$ His vision for a small force, having good organisation and excellent supply, but with "not too much discipline", was countered by the Unionists. The Unionists demanded a force not only sufficient for internal defence, but able also, in concert possibly with British forces, to repel the attack of a European enemy possibly elsewhere in British Africa.

Opposing his own party, Smuts introduced the South Africa defence bill in February 1912. An avalanche of criticism and high levels of discontent in the country districts of particularly the Transvaal followed. ${ }^{22}$ There remained, as Hugh Wyndham noted, "a great deal of suspicion of its provisions amongst the old fashioned Boer population" and mostly regarding the principle of compulsory training. ${ }^{23}$ Petitions were considered, the Military Code and Rules of Procedure as provisionally adopted from the British Army Act were consulted, and in the face of severe opposition the bill was adopted in April 1912. ${ }^{24}$ As a party, only the Unionists were satisfied, for the bill stressed the importance of defence as an imperial matter. ${ }^{25}$ However, this legislation contained the seed of its own near destruction. "South Africa", as used in the Act, was a geographic expression, left purposely undefined by Smuts, although he had assured the governor-general that "it would surely cover any part of the continent of Africa south of the equator". ${ }^{26}$ However inadequate the UDF was, it represented a fundamental change in South African military policy. The Defence Act recognised a dependence on the Royal

19. These conferences were convened, in Pretoria, Durban, and Johannesburg, and were followed by the Imperial Conferences of 1909 and 1911. Debatten van de Volksraad, 21 February 1911, cols 1263-66. See also, War Office Documents, A1380, South African Defence.

20. Rhodes House, Oxford (hereafter RHO): Sir Herbert James Stanley Papers, MSS Afr s.1250, Herbert Stanley to Lord Gladstone, 7 August 1910. Kent Fedorowich is thanked for this reference.

21. J.X. Merriman to M.T. Steyn, 16 January 1911, in A.H. Marais (ed.), Politieke Briewe, II: 1911-1912 (Tafelberg, Bloemfontein, 1973), p 5.

22. NASAP: Beyers Collection, col 1, ff. 45-47, M.T. Steyn to C.F. Beyers, 16 February 1912. See also the two petitions, Memorial of the Women of Nooitgedacht, undated (ff.104-107), and Memorial of the Women of Randjesfontein, undated (ff.108-110).

23. WSRO: PHA, Hugh Wyndham to Lady Leconfield, 21 February and 27 February 1912.

24. Union of South Africa, Parliament, Select Committee Report: S.C.7-1912. On South African Defence Bill, see report, J.C. Smuts, 16 April 1912.

25. RHO: Feetham Papers, Box 3, file 1, folio 134, Richard Feetham to his mother, 19 April 1912.

26. Smuts did not consider the term "South Africa" in any way limited by the Act of Union. SANDF Documentation Centre, Pretoria: DC, Box 47, file 1063, South African Defence Bill, Smuts to Lord Gladstone, 16 November 1911. 
Navy to protect South Africa from foreign invasion and there were now coastal defences backed by military forces on the interior. But few thought the UDF would undertake military tasks beyond "South Africa", and so the UDF remained essentially a colonial constabulary and coast-defence organisation with few sharing Smuts' vision for a more balanced, modern force, capable of engaging a modern enemy.

\section{The Union Defence Force and the politics of military integration}

Like the Union of South Africa, the UDF was a compromise between the determination of English-speakers to maintain the "British connection" and the desire of Afrikaner nationalists for a restoration of Boer political and military traditions. It was self-evident - despite the appeals of Olive Schreiner and others that the new South African state founded in 1910 was to be a militaristic if not well armed society. The Union Defence Forces was thought by politicians across party lines to be both natural and inevitable. But it was less evident how exactly members of four disparate forces, representing at least three military traditions, and speaking and protecting two languages, were to combine into the defence structures.

This conundrum faced Smuts, who, like his early rivals, J.B.M. Hertzog and C.F. Beyers, had seen service in the Boer armies, when they had commanded fronts and planned strategy against the British. Smuts, who recognised that the future of the UDF lay not in the re-creation of the Boer forces or in the sole efforts of former Boer commanders, appreciated the need for a modern defence force based on Western methods. He was undoubtedly the overwhelming influence behind the UDF and relied, at times heavily, upon carefully selected staff officers, of whom the foremost, Tim Lukin, Roland Bourne, and Jack Collyer, were his former enemies. Always expedient, Smuts recruited talent, well-trained, experienced, battle-hardened, even if they came from former colonial or British regiments. ${ }^{27}$ But this and Smuts' easy erudition was not well-received in the backveld. $^{28}$

In the face of severe Afrikaner opposition, the Union Defence Forces (UDF) were established with effect from 1 July 1912. The Union Defence Forces, which drew in structures from the four former colonies ${ }^{29}$, was itself a combination of six forces - the SA Permanent Force (SAPF), the Active Citizen Force (ACF), the Coast Garrison Force (CGF), the Rifle Associations (or resurrected Commandos), the Royal Naval Volunteer Reserve (RNVR), and the Cadet Corps. The UDF, in

27. Field Marshal Lord Methuen and his chief of staff, Brigadier General George Aston, were also consulted and, at Smuts' request, both men remained in South Africa until the passage of the bill through the South African parliament. SANDF Documentation Centre, Pretoria: DC, Box 47, file 1063, South Africa Defence Bill.

28. William Cullen Library, University of the Witwatersrand (hereafter Wits): Archives of the Church of the Province of South Africa, AB186, Archbishop Carter Letters, William Carter to Algernon Lawley, 3 August 1919, The term "backveld" was used by the English South Africans to refer to "the rolling countryside of the two old republics". See A.G. Barlow, That We May Tread Safely (Tafelberg, Cape Town, 1960), p 66. Barlow's definition, however, does not suggest the pejorative meaning that the term conveyed.

29. These were the Cape Colonial Forces, the Transvaal Volunteers and the Natal Militia, as well some former members of the South African Constabulary, a paramilitary police force for the Transvaal and Orange River colonies. 
terms of the Defence Act, was created for the defence of "South Africa" and it encompassed the traditional cornerstones of South African military policy, namely, citizen soldiers, a small permanent force, a small local division of the Royal Naval Volunteer Reserve, which was stationed at the major ports only, and very thinlyspread coastal fortifications. However, several factors affected the Union Defence Forces and undermined its standing as a reliable, well-equipped, and deployable defence force.

Firstly, there was the matter of military culture. Complex dynamics, embracing personal prejudice as much as the demands of modern warfare and the requirement of imperial standardisation, shaped South African defence policy and the formation of the Union Defence Forces. However, the UDF remained an unhappy marriage between the British and Boer military value systems. A Defence Council, essentially a safety mechanism for the protection of language interests, was created. ${ }^{30}$ But many Afrikaners could not endure "the melting pot" of the new Union Defence Forces, and appealed to old patrons for personal support or, eventually, followed them into rebellion in $1914 .{ }^{31}$ Several explanations, chiefly from the Afrikaner nationalist perspective, have been provided for the alleged heavy British imprint on the Union Defence Forces. These range from the length of Britain's presence in southern Africa and her pre-eminent position after 1902, to the blaming of Smuts and Botha for their abandonment of the volk and their embracing of empire. ${ }^{32}$ Yet, while each of these explanations has merit, they remain, even collectively, inadequate. Historians generally have not assessed the role of the individuals behind the establishment of the UDF, the nature of that force, and the specific purposes for which it was designed. The UDF was a consensus, a product of a combination of systems, but nonetheless a thoughtful combination, one (hopefully) of "proper conception". ${ }^{33}$

Second was the apparent need, even at the cost of military effectiveness, to balance language and sectarian interests. This is evident from the start. The parliamentary select committee for defence, to which the bill was referred in March 1912, comprised nine members (four Afrikaners and five English-speakers) with a political division of four Unionists, four members of the "Dutch" party, and one

30. There were four defence councillors, two English and two Afrikaans, and representing the four provinces. See SANDF Documentation Centre, Pretoria: DC, Box 109, files 2270 and 2271 Defence Council Agenda of 1st and 2nd meetings. See also I. van der Waag, 'Smuts' Generals: Towards a First Portrait of the South African High Command, 1912-48", War in History, 18, 1, 2011, pp 33-61.

31. NASAP, General C.F. Beyers Collection, Vol. 1, Beyers to Sir John French, 21 July 1913 ("the melting pot"). There are also numerous references to instances of nepotism and "connection" support in J. Kemp to Beyers, 5 April 1909; M.T. Steyn to Beyers, 30 September 1913; Smuts to Beyers, 27 February 1914; "Maurits" to Beyers, 8 June 1914 (all in NASAP, Beyers Collection, vol. 1). See also NASAP, Col M. du Toit Collection, W.77.1, in the correspondence between Colonel du Toit and former president M.T. Steyn, 1912.

32. G.D. Scholtz, Generaal Christiaan Federik Beyers 1869-1914 (Voortrekkerpers, Johannesburg, 1941); J.C.G. Kemp, Die Pad van die Veroweraar (Nasionale Pers, Cape Town 1942); G.D. Scholtz, Hertzog en Smuts en die Britse Ryk (Tafelberg, Cape Town 1975); L. Jooste, "Die Politieke Koerswending van 1948 Besorg 'n Nuwe Identiteit aan die Univerdedigingsmag", Militaria, 26, 2, 1996, pp 113-128; L. Jooste, "F.C. Erasmus as Minister van Verdediging, 1948-1959", MA thesis, Unisa, 1995, pp 13-14.

33. Wyndham, "Some Aspects of South African Defence", p 651. 
Labourite, and representative of force of origin and province. ${ }^{34}$ Even the specialists this select committee interviewed represented the British-colonial and Boer military systems in almost perfect equity. A prosopographical study of the South African high command during this period shows, moreover, that the split between the language groups was exceptionally fine (Table 1). The drive for language equity was seemingly the preferred way for finding a consensus in a difficult environment characterised by competing military traditions and language preferences. ${ }^{35}$

\begin{tabular}{l|cc}
\hline Category & English & Afrikaans \\
\hline $1912-20$ & 8 & 11 \\
$1920-30$ & 2 & 3 \\
$1930-40$ & 4 & 1 \\
$1940-50$ & 17 & 15 \\
\hline Total & 31 & 30 \\
\hline
\end{tabular}

Table 1: Career point and language of South African high command ${ }^{36}$

Thirdly, and relating to this matter of equity, was the appointment of the high command. This was a difficult political decision and when the various arms of the Union Defence Forces came into being in 1913, the whole was placed under a divided command to protect sectarian interests and also diminish the possibility of a coup. The two most important positions were filled by Lukin, the former commander of the Cape Colonial Forces, and the staunchly republican, former-general C.F. Beyers. Lukin's was arguably the more important post in the new structure; he had to create an atmosphere in the Permanent Force that was congenial to both English and Afrikaans-speaking South Africans, which through personal fairness, impartiality and professionalism, he achieved to a remarkable degree. ${ }^{37}$

Beyers, the commandant general of the Citizen Force, was cut from different cloth, which introduces a fourth matter, that of the military factions created before 1912 in the struggle for military power and the rush on the available posts in the new structures. Beyers and several other high-ranking officers provided organisationally for their clients and political followers; Beyers, when head of the Citizen Force, even emptying the citizen regiments of their more "British" officers. ${ }^{38}$ This, as Charles Leonard complained, worked towards "permanent alienation instead of reconciliation" ${ }^{39}$ and affected the unity of the Union Defence Forces materially. Wyndham, pushed out of the Citizen Force in 1912, had noted somewhat

34. Debatten van de Volksraad, 7 March 1912, col 736; and Union of South Africa, Parliament, Select Committee Report: S.C.7-1912. On South Africa Defence Bill, p ii.

35. NASAP: General C.F. Beyers Collection, Vol 1, J.C. Smuts to C.F. Beyers, 9 May 1914, and "Maurits" to C.F. Beyers, 8 June 1914.

36. Van der Waag, "Smuts' Generals", p 51.

37. E.W. Nortier, "Major General Sir H.T. Lukin, 1861-1925: The Making of a South African Hero", MMil thesis, Stellenbosch University, December 2005.

38. NASAP: General C.F. Beyers Collection, Vol 1, J. Kemp to C.F. Beyers, 5 April 1909, and M.T. Steyn to C.F. Beyers, 16 February 1912; NASAP: Col M. du Toit Collection, C.F. Beyers to M. du Toit, 23 December 1912. See also, Kemp, Die Pad van die Veroweraar, $p$ 109.

39. NASAP: Charles Leonard Papers, Charles Leonard to David Graaff, 17 February 1903. 
prophetically two years earlier that Beyers was "a very violent Boer", capable of making "very racial speeches" and that if he were made "Minister of Defence, or Commandant General, [this] would lead to the dismemberment of any defence force that we may possess at present or in the future". ${ }^{40}$ The establishment of organisational fiefdoms stunted development and the UDF failed to employ officers with the appropriate military training and education. And then, to complicate the complexity of this situation even further, there was the presence of two British commands in South Africa, which although a military necessity, was the cause of political mischief of a two-way flow, pressing Pretoria to "demonstrate independence".

These local British commands together form a further factor. The British Army command headquartered in the Castle, at Cape Town, and the Royal Naval base at Simonstown, presented problems that were political and military, necessary for the adequate defence of South Africa, but simultaneously a visible sign of South Africa's constitutional and military dependence. South Africa's answer, to invoke one British high commissioner, Sir William Clark, was "to devise some difference of method so as to demonstrate South Africa's independence". ${ }^{41}$ Unsurprisingly, relations between South African officials and their often-shirty, British counterparts, were often difficult and reached several nadirs during the First World War and then during the 1930s. Smuts and his generals, for example, did not bother to consult the commander of the imperial command in South Africa when war erupted in 1914, which angered Major General C.W. Thompson and his naval counterpart in Simonstown, the commander-in-chief of the Royal Navy's Africa Station. Often Anglo-South African co-operation was a matter of personality. Brigadier-General A.E.J. Cavendish was recalled in 1917, after a speech in which he described Smuts, then in the British war cabinet, as "that modern miracle" who "for (the) beaten enemy ... had a very nasty knack of asserting himself at times". ${ }^{42}$ Imperial distrust of certain South African officers confirmed by the outbreak of rebellion in 1914 and Beyers' Macbeth-like hesitation had exacerbated this. Similar friction arose during the build-up to 1939, when the South African government seemingly refused to co-operate with the British admiral in Simonstown and in 1940 , much to the chagrin of local RN men, manufactured conditions that enabled Pretoria to create her own navy. ${ }^{43}$

Moreover, the stark economic environment of the 1910s and 1930s and the resulting financial austerity, forced Union ministers throughout this period to look to South African interests first. However, in terms of military policy the UDF found itself caught increasingly between its traditional role of colonial pacification and the heightening possibility of a foreign deployment. There was a lack of specificity and

40. WSRO: PHA, Hugh Wyndham to Lady Leconfield, 2 November 1910.

41. UCT: BC81 Papers of Sir W.H. Clark, Ca5, Sir William Clark to Sir Edward Harding, 8 March 1937.

42. SANDF Documentation Centre, Pretoria: DC, Box 1142, file DCDB 2394/7, Speech by General Cavendish at a meeting of the St. John's Ambulance on 2 November 1917. See also suggested recall of Brigadier General Cavendish G.O.C. South African Military Command and appointment of General Martyn.

43. The National Archives, Kew, London (hereafter TNA): DO 35/1008/7 WG 429/13, Peter Clutterbuck to J.E. Stephenson, 29 September 1939. See also I. van der Waag, "The Thin Edge of the Wedge: Anglo-South African Relations, Dominion Nationalism and the Formation of the Seaward Defence Force in 1939-1940", Contemporary British History, 24, 4, 2010, pp 427-449. 
no clear object; who can forget the reply of former Boer general, Coen Brits, to Botha's request for support in 1914: "My men are ready; who do we fight - the English or the Germans?"44

The strategic framework of the period was complex and fraught with difficulties, which were at once political, cultural, economic and organisational. There was, of course, interplay between individual leaders and their past experiences and their approach to military innovation, and the cultural climate of the Union's new military structures. Military leaders and their political masters had no consensus on who the potential enemies were, although the services viewed the defence of South Africa (possibly a geographic and not solely a political term) against a possible landward onslaught as their overall strategic mission. The services were always cash-strapped and competed, certainly during interwar years, for the shrinking pool of resources. As a result, the UDF enjoyed only difficult access to technological resources and there was seldom congruence between political objectives and force capabilities. And then, the experiences of the 1914-18 war shaped the strategic environment and the preparations for future conflict considerably.

\section{Experience of war, 1914-1918}

South Africa's decision to enter the First World War and assist Britain in the struggle was not easy. Many Afrikaners recalled the assistance they had received from Germany in their recent war against the British and for many, Britain's claim made in 1914 with regard to Belgium that she would protect small nations, seemed incredulous. ${ }^{45}$ Moreover, South Africa was not a united country in 1914 . There was no South African nation, no consensus on the war. In August and September 1914 , the war suddenly brought the constitutional relationship with Britain and the British Empire into sharp relief. ${ }^{46}$

In 1914, South Africa, tied constitutionally to Britain, could not choose her allies. Besides, nationally, Botha, former Boer general and now wartime prime minister, found himself between two camps: a "British" sector, wanting to involve South Africa in the war fully, and an Afrikaner camp, wanting South Africa to stay out. The first considered it South Africa's duty, as a loyal dominion of the empire, to freely support the British war effort. In fact, during the 1912 defence debate, the Unionists had predicted a time when South Africa would not only have to assume responsibility for her own defence, so freeing British assets for service elsewhere, but also offer the "old country" the support of a South African expeditionary force. ${ }^{47}$

44. As quoted by G. L'Ange, Urgent Imperial Service: South African Forces in German South West Africa, 1914-1915 (Ashanti, Rivonia 1991), p 4.

45. H. Strachan, The First World War in Africa (OUP, Oxford, 2004), p 64.

46. L. Koorts, DF Malan and the Rise of Afrikaner Nationalism (Tafelberg, Cape Town, 2014), pp 105-17. See B. Nasson, WWI and the People of South Africa (Tafelberg, Cape Town, 1914) for an entertaining narrative of this period. On the changing position of black and coloured South Africans, see A. Grundlingh, War and Society, Participation and Remembrance: South African Black and Coloured Troops in the First World War, 19141918 (SUN Press, Stellenbosch, 2014) is equally excellent.

47. P.F. van der Schyff, "Die Unioniste Party in die Suid-Afrikaanse Politiek, 1910-1921", M.A. dissertation, PU for CHE, 1964), p 72. 
To Afrikaner nationalists this was anathema. M.T. Steyn, writing to Smuts on 31 July 1914, reckoned that:

\begin{abstract}
the troubles in England are the result of the South African War. One sees still more. This war has driven England out of her "splendid isolation" into her "ententes" and her yellow alliances and today she has fallen foul of Continental entanglements. The mills of Providence grind slowly indeed! ${ }^{48}$
\end{abstract}

Republican Afrikaners had longed for this in 1900. Now, fourteen years later, this had seemingly happened and there was new hope. The Afrikaner nationalist saw no reason whatever to help Britain. They might, as Steyn was suggesting, rather seize the moment presented providentially as an occasion for a small people to assert their claim for independence, even militarily if necessary.

Botha, perhaps naively, had hoped to unite the country behind the war effort, and so strengthen longer term bonds. This was, as Francey Malan noted, "wonderful politics" and Botha succeeded to a surprising degree in quietening the voice of radical labour and nationalistic Africans. However, as Malan predicted, by committing South Africa to the war, Botha ran "the danger of losing the sentiment of the [Afrikaner] people". ${ }^{49}$ The war and the questions it opened raised African expectations and fuelled Afrikaner nationalism. Botha therefore battled to achieve and then maintain consensus in his cabinet. Faced with potential defections and the growing rift in Afrikanerdom, his first wartime ministry was unstable and his second ministry, formed after the October 1915 election, could only govern with Unionist support, though not in formal coalition.

South Africa's military task was, moreover, complicated. Not only was the UDF little more than two years old, but South Africa, as John Buchan reminds us, had "foes within and without her gates" 50 and her task, "of all the nations of the British Commonwealth ... [was] at the outbreak of war the most intricate" ${ }^{51}$ At the beginning of August 1914, South Africa duly offered to take care of her own defence, so freeing imperial troops for deployment to France - they were not to return. ${ }^{52}$ The defences of South Africa were now for the first time manned solely by the new UDF, some of whom, disliking the tedium of garrison duties and the manning of home defences, were anxious to form a South Africa expeditionary force. Failing this some left to join the British Army. ${ }^{53}$

48. M.T. Steyn to J.C. Smuts, 31 July 1914, in W.K. Hancock and J. van der Poel (eds), Selections from the Smuts Papers, Vol 3: June 1910-November 1918 (Cambridge University Press, Cambridge, 1966), p 184.

49. NASAC: A583, F.S. Malan Collection, Volume 22, Diary of F.S. Malan, 9 August 1914. See also F.A. Mouton, Prophet without Honour, F.S. Malan: Afrikaner, South African and Cape Liberal (Protea Book House, Pretoria, 2011), chapter 7.

50. J. Buchan, The History of the South African Forces in France (Battery Press, Nashville, 1992), p 13. See also Emily Hobhouse to J.C. Smuts, 8 August 1914, in Hancock and Van der Poel (eds), Smuts Papers, Volume 3, p 185.

51. Buchan, The History of the South African Forces in France, p 13.

52. The South African Military Command closed with effect from 1 December 1921. SANDF Documentation Centre, Pretoria: DC, Box 886, file Q.23892, Transfer South African Military Command to Union Defence, Secretary for Defence to the Headquarters, SA Military Command, 28 September 1921.

53. WSRO: PHA, Hugh Wyndham to Lady Leconfield, 13 August 1914. 
South African defence in the age of total war

\begin{tabular}{l|rrr}
\hline & White combatants & $\begin{array}{r}\text { Coloured } \\
\text { combatants }\end{array}$ & Black labourers \\
\hline South Africa & 5082 & & 7267 \\
South West Africa & 67237 & & 33546 \\
East Africa & 43477 & 1925 & 25111 \\
Egypt and France & 30179 & & \\
In British Army (approx) & 6500 & & \\
\hline
\end{tabular}

Table 2: Military participation in the First World War ${ }^{54}$

For the fledgling UDF, her series of complex and divergent campaigns commenced with the purpose of neutralising the radio stations in the German colony of South West Africa. This campaign was suddenly suspended, while attention was diverted to the Afrikaner rebellion. When this was put down, the South West campaign recommenced. An infantry brigade helped quash the Senussi in Egypt before being practically annihilated at Delville Wood in France. The brigade, accompanied to the Western Front by a field ambulance and a general hospital, had to be reconstructed more than once. Two brigades of heavy artillery, a signal company, a railway company, an Auxiliary Horse Transport Company and a South African Native Labour Contingent (SANLC) also served in France, but not in association with each other or the infantry brigade. A large South African force broke German resistance in East Africa; while a brigade of field artillery and later the Cape Corps served in Egypt and Palestine (Table 2). Numerous South Africans were recruited into the Royal Air Force; some 6500 volunteered for service in imperial units; and all the while the conquered territory of South West Africa was garrisoned by occupation troops, who, in the words of the official historians, had "a successful little native campaign of their own". 55

54. Adapted from Official Yearbook of the Union of South Africa 1922 (Government Printer, Pretoria, 1922), p 399.

55. Anon., The Union of South Africa and the Great War: Official History (Government Printer, Pretoria, 1924). Although Wyndham and Collyer, and possibly Smuts, all made contributions, Leipoldt was probably responsible for the bulk of this work. Jan Ploeger came to a similar conclusion in 1989, although he unfortunately did not present his evidence. See J. Ploeger, "Suid-Afrikaanse Staats- en Staatsondersteunde Militêre Geskiedskrywing, 1924-1987", Militaria, 19, 4, 1989, p 19. 


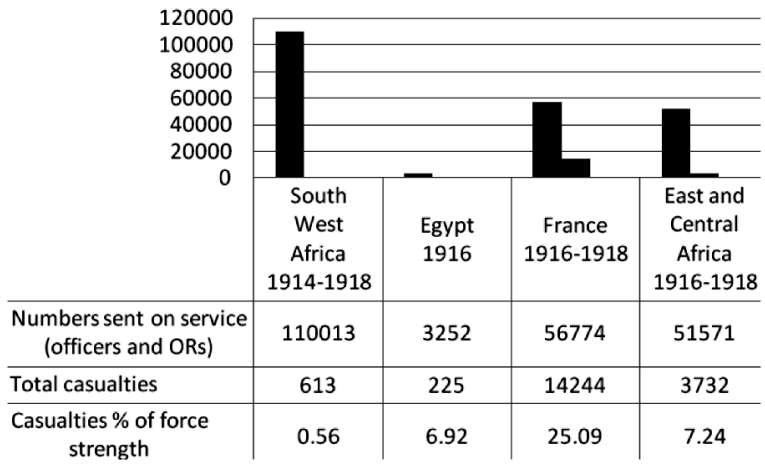

Figure 1: South African casualties (battle related): a comparative campaign perspective

Note: these figures include "killed in action" as well as "wounded in action".

For the allied powers, the ostensible victors, victory was bittersweet. For South Africa, this was little different. Although the country emerged physically unscathed, the price tag, in money and sacrifice, was high. ${ }^{56}$ The numbers of South African casualties were relatively small. Battlefield casualties (killed and wounded in action) were particularly low for the African campaigns, numbering 0.56 percent of force strength in German South West Africa; 6.92 in Egypt and 7.24 in German East Africa. This rose to 25.09 percent for the campaign on the Western Front (Figure 1). But this was also low when compared with the other dominions. The total killed during the war (1914-1918) was 9 percent of those serving abroad, the next lowest was Canada at 12 percent. Most of the 7121 South African killed during the war had died on the Western Front (Table 3). For South Africa, a country accustomed to limited wars and low own-force casualties, these losses were unacceptable. Furthermore, the war, together with the rebellion and rumour of rebellion, had come at a political cost, increasing as it did popular suspicion of government, leaders, and institutions like the military. It discredited Botha and Smuts, the wartime ministers, and, although temporarily aligning South Africa with the allied powers, estranged Smuts and those of broader vision from the mass of Afrikaners.

56. A serious study of the impact of the war on South African society is still lacking. For comparative works see R. Bourne, Britain and the Great War, 1914-1918 (Edward Arnold, London, 1989); A. Marwick, The Deluge: British Society and the First World War (Little, Brown \& Co, Boston and Toronto, 1965); A. Marwick, "The Impact of the First World War on Britain", Journal of Contemporary History, iii, 1, 1968; A. Marwick, War and Social Change in the Twentieth Century: A Comparative Study of Britain, France, Germany, Russia and the United States (Macmillan, Basingstoke, 1974); J. Winter, The Great War and the British People (Macmillan, Basingstoke 1985); and J. Winter, The Experience of World War 1 (OUP, Oxford, 1988). 


\begin{tabular}{|c|c|c|c|c|c|c|c|}
\hline & $\begin{array}{c}\text { Total } \\
\text { recruited }\end{array}$ & $\begin{array}{c}\text { Total } \\
\text { recruited } \\
\text { as } \% \text { of } \\
\text { male } \\
\text { population }\end{array}$ & $\begin{array}{c}\text { Total } \\
\text { serving } \\
\text { abroad }\end{array}$ & $\begin{array}{l}\text { Total serving } \\
\text { abroad as \% } \\
\text { of total } \\
\text { recruited }\end{array}$ & $\begin{array}{l}\text { Total } \\
\text { killed }\end{array}$ & $\begin{array}{c}\text { Total } \\
\text { killed as } \\
\% \text { of } \\
\text { total } \\
\text { recruited }\end{array}$ & $\begin{array}{l}\text { Total } \\
\text { killed as } \\
\% \text { of } \\
\text { serving } \\
\text { abroad } \\
\end{array}$ \\
\hline $\begin{array}{l}\text { United } \\
\text { Kingdom }\end{array}$ & & 22 & & & & & \\
\hline Canada & 628,964 & 14 & 458,218 & 73 & $\begin{array}{r}56,63 \\
9\end{array}$ & 9 & 12 \\
\hline Australia & 412,953 & 14 & 331,814 & 80 & $\begin{array}{r}59,33 \\
0\end{array}$ & 14 & 18 \\
\hline New Zealand & 128,525 & 20 & 112,223 & 87 & $\begin{array}{r}16,71 \\
1\end{array}$ & 13 & 15 \\
\hline $\begin{array}{l}\text { South Africa } \\
\text { India }\end{array}$ & $\begin{array}{l}136,070 \\
683,149\end{array}$ & 10 & $\begin{array}{r}76,184 \\
1,096,01 \\
3\end{array}$ & 56 & $\begin{array}{r}7,121 \\
65,05 \\
6\end{array}$ & 5 & 9 \\
\hline
\end{tabular}

Table 3: Contribution of imperial and dominion troops to war effort, 1914-1918 ${ }^{57}$ - This figure is a percentage of the white, male population.

This was, of course, not a phenomenon uniquely South African. Generals, across the board, were blamed for the costly failures of the war. Military commanders on all sides were criticised and severely so, for the apparent waste of human life in a succession of offensives that gained little. Many South Africans saw Delville Wood as an example of this callousness. Some like Maud Wyndham, the wife of the shadow defence minister, went a step further. She blamed these military "muddles" on the Allied generals whom she accused of incompetence and lacking in the mental dexterity needed to effect a tactical and strategic breakthrough. But she was even more critical of the politicians, who she believed were self-serving and did not support the fighting generals with a workable and realistic grand strategy to win the war. She was striking an important note: a total war demands excellent leadership, political and military, that can work together in unison toward larger national objectives. "Providence", she lamented at the end of 1915, "has not given us a Chatham and a Marlborough to guide us thro' this period". ${ }^{58}$

Yet, although it was "no use girding against the poor minnows we have got", Mrs Wyndham was convinced, as many South Africans were, that "there [were] things even a minnow might avoid". ${ }^{59}$ The South African leadership, although praised in Britain for their stance, was at times, for both the British sector in South Africa as well as the Afrikaner right, an object for amusement and of scorn. Some soldiers derided the politicians for their apparent willingness "to fight to the last drop

57. Adapted from A.S. Thompson, Imperial Britain; The Empire in British Politics, c.1880-1932 (Pearson, Harlow, 2000), p 158.

58. WSRO: PHA, Maud Wyndham to Lady Leconfield, 8 December 1915. Mrs Wyndham, incidentally, was born a Lyttelton of Hagley. She was descended from the core of the governing families of eighteenth- and nineteenth-century Britain and her ancestors included both Chatham and Marlborough. Of this she had also been aware.

59. WSRO: PHA, Maud Wyndham to Lady Leconfield, 8 December 1915. 
of blood of the soldiers at the front". 60 They, the politicians, were the true enemy; the soldiers, collectively, their victims. They were innocent and their sacrifice almost Christ-like. Emily Hobhouse blamed the politicians, "who make troubles", for sending the troops in to be killed. ${ }^{61} \mathrm{~N} . \mathrm{W}$. Nichol, vocalising a popular sentiment, reckoned that "there is no doubt the politicians ought to get it in the neck, it's an awful shame that the soldiers should be the only ones to suffer". ${ }^{62}$ They had been exposed to the brutality of warfare in Europe supposedly without proper training. There was a notion that colonial volunteers ought not to have been thrown into the line against German militarism.

\section{Post-war strategic calculations}

More than a quarter of a million South Africans served on the different fronts during the Great War, involving nearly ten percent of the total white population and some twenty percent of the male white population (Table 3). More than thirty thousand South Africans experienced the horror of trench warfare on the Western Front, the accompanying devastation and the shocking casualty statistics. For South Africans, attuned to small wars, limited "native" campaigns, chiefly of pacification, and accustomed to low own force casualties, the change to total warfare and the experience of the Western Front was cataclysmic. The South African stand at Longueval and Delville Wood lasted almost one week, from midday on July 14 to dusk on July 20, 1916. This was the most expensive week in South African military history until surpassed by the defeat at Sidi Rezeg (1941) and then the surrender at Tobruk (1942). ${ }^{63}$

Nowhere was the impact of the Western Front for South Africa greater than on the nation's foreign policy. The war shattered any possibility for post-rebellion, national reconciliation and left South Africans confused and deeply divided on the goals to be pursued and methods to be used. Even before it had ended, the traumatic experience of the war, combined with the apparent improvement of relations between some Afrikaners and some English-South Africans, and a growing preoccupation with domestic problems, produced a drastic reordering of national priorities. Smuts had placed foreign policy consistently near the top of the ranking of national concerns, but by Hertzog's first term of government it was placed well down on the priority list. ${ }^{64}$

60. UCT: BC643 Joyce Newton-Thompson Collection, B1.53, Lt Cyril Newton-Thompson to Joyce Nettelfold, 21 July 1916.

61. Emily Hobhouse to J.C. Smuts, 8 August 1914, in Hancock and Van der Poel (eds), Smuts Papers, Volume 3, p 186. This idea still has currency in South Africa. See, for example, G. Mills, "Canon Fodder for Man's First Mechanised Mass Murder", The Sunday Independent, 13 February 2005, p 17: "They were brave, but the war itself was a costly folly and the political leaders who caused it were callous and inept."

62. UCT: BC477 Purland Family Collection, N.W. Nichol to Capt T. Purland, 1 August 1917.

63. The political impact of the fall of Tobruk is treated superbly by A. Stewart, "The 'Atomic' Despatch: Field Marshal Auchinleck, the Fall of Tobruk Garrison and Post-War AngloSouth African Relations", Scientia Militaria, South African Journal of Military Studies, 36, 1, 2008, pp 78-94.

64. The Smuts and Hertzog premierships are treated in D.W. Kruger, The Age of the Generals; A Short Political History of the Union of South Africa, 1910-1948 (Dagbreek, n.p., 1958); and Scholtz, Hertzog en Smuts, a study that has unfortunately not found publication in English. The South African military during the interwar period has been address in I. van der Waag, "The Union Defence Force between the Two World Wars, 1919-1940", Scientia Militaria, 30, 2, 2000, pp 183-219. 
In the very different climate of the mid-1920s, the debate over the war that had not fully taken place at the war's end assumed a central place in the larger and at times quite vocal debate over South African foreign policy. The basic issues remained. Firstly, there was the question of the morality of the intervention. Ought South Africa to involve herself in foreign, imperial wars? And, closely associated with this, was the aversion for technological warfare, for the materielschacht. ${ }^{65}$ Smuts himself wrote: "There is much to make us profoundly sad and almost to despair of the future of the race when we see our greatest intellectual and scientific discoveries turned like so many daggers at the heart of civilization." 66

The individual had to be recovered and returned to the centre stage; something it seemed that could be done more easily in Africa, where human skill seemed to count for more. This raises the second matter, the wisdom of the intervention. Europe, simply stated, was not the place for South African military ventures. The campaigns in German South West and East Africa had been, as Buchan noted, "frontier wars, fought for the immediate defence of her borders and her local interests". ${ }^{67}$ Sub-Saharan Africa was South Africa's backyard and the only theatre to which post-1924 nationalist governments would consider sending South African troops. Warfare in Europe had to be avoided and after 1924 and the advent of the first nationalist government, the Union Defence Force refocused on Africa, where asymmetry would be to her advantage and was seemingly more suited to the South African way of war. France and the Western Front had been geographically foreign, and its circumstances militarily unfamiliar. ${ }^{68}$

Geography and post-Versailles politics had combined to give South Africa reasonably safe and defensible borders. The 1922 Smuts-Churchill agreement left the Royal Navy responsible for the protection of the coastline and, with Simonstown now recognised as a British naval base, all of the reasonable risks of war seemed effectively covered. Germany had been driven out of Africa, German South West was in South African hands, and Tanganyika had gone to Britain. There was now no apparent danger of attack overland and, in any case, the overland routes were limited, the potential European enemies geographically distant, and African opponents at a technological disadvantage. The Hertzog government, which came to power in coalition with Labour in 1924, could as a result settle into an easy military economy.

65. The repercussions of industrialised warfare have been addressed by A.R. Millett and W. Murray, Military Effectiveness, Volume 1: The First World War (CUP, Cambridge, 2010); T. Travers, The Killing Ground: The British Army, the Western Front, and the Emergence of Modern Warfare, 1900-1918 (Allen \& Unwin, London, 1987) and How the War Was Won: Command and Technology in the British Army on the Western Front, 1917-1918 (Routledge, London, 1992); A. Ashworth, Trench Warfare, 1914-1918: The Live and Let Live System (Macmillan, London, 1980); and others.

66. Smuts to Wolstenholme, 29 November 1915, in Hancock and van der Poel (eds), Smuts Papers, Volume 3, pp 324-325.

67. Buchan, The History of the South African Forces in France, p 260.

68. See Merriman's speech quoted in "Union's Roll of Honour. Deathless Deeds at Delville Wood", presented at the Musical Memorial Service in the City Hall. See also "Mr Merriman on South Africa's Heritage", Cape Times, 19 July 1917, p 6. 
Moreover, when in opposition, Hertzog's National Party had equated military and industrial power with Smuts, holism and a Greater Britain. ${ }^{69}$ The war experience had provoked strong Afrikaner opposition, particularly against support of Britain and objectives perceived to be British and imperial rather than South African. They had opposed South African support for British attempts to rescue Greece and the intoxicated Eleftherios Venizelos during the Chanak crisis. Dr D.F. Malan (NP, MP Calvinia), noted: "The Dardanelles are not worth a drop of our blood or a shilling of our money; South Africa should proclaim her neutrality." ${ }^{70}$ Tielman Roos (NP, MP Lichtenburg) was quoted as follows:

Ons is absoluut daarteen gekant om die Unie te stoot in die bynes van Europese en Asiatiese politiek en oorloë. Dus sal die Nasionale Party veg teen die versending van ' $n$ enkele Afrikaner-Engels- of Afrikaans-sprekende - en die uitgawe van ' $n$ enkele pennie in verband daarmee. ${ }^{71}$

(We are absolutely opposed to pushing the Union into the beehive of European and Asian politics and wars. The National Party will therefore fight against the despatch of a single South African and the expense of a single penny in this connection.)

Nationalist politicians followed this line from the start and, after their electoral success in 1924, implemented increasingly a policy of neutrality.

There were several constraints, however. For one, there was no common vision on who constituted the most likely enemy. The post-war threat assessment identified several potential enemies and possible theatres of operations; interestingly, the threat perceptions had changed little since the turn of the century. There was theoretically, after Germany's defeat, always a non-African power able to project force inter-continentally. During the 1920s this was France. During the 1930s Italy and Germany were assessed the greater threat. Nationalist politicians, and their supporters within the military, reckoned Britain a threat, either as a possible foe or as the mechanism through which South Africa would be dragged into another war.

There was also the threat of landward invasion from continental Africa, which might take the form of a colonial power with imperial objectives or the possibility of an African revolt against colonial rule sweeping south, possibly a mutiny by the Force Publique of the Belgian Congo. ${ }^{72}$ Three assumptions underlay nationalist policy: there would be time for mobilisation; the war would be mobile and in the African bush north of the border and South African cities and towns would be safe from air attack. ${ }^{73}$ The third threat, omnipresent since 1906, was an

69. See, for example, SANAC: A608 Fremantle Collection, Volume 14, Fremantle to Hertzog, 12 November 1923.

70. "Dr Malan en die Dardanelle", Volkstem, 2 September 1922. Translated from the original Afrikaans: "Die Dardanelle is nie 'n druppel van ons bloed of ' $n$ sjïeling van ons geld wêrd nie, en Suid-Afrika behoort hom neutral te verklaar.

71. "Geen Man en Geen Pennie; Ons Leier oor die Wereld-krises", Ons Vaderland, 22 September, 1922.

72. Information extracted from War Office, Admiralty and RAF files by Capt. F.H. Theron in September 1929. SANDF Documentation Centre, Pretoria: DCS, Box 3, file SP 9, Capt Theron's attachment to War Office report on "Belgian Military Forces in Congo: Extract from Report of Colonial Ministry".

73. D. Cowie, "Union of South Africa", Journal of the Royal United Service Institution, 84, 1939, pp 262-263. 
internal uprising by African nationalists or syndicalised labour within South Africa itself.

For the first contingency there was the Royal Navy. But for the second and particularly the third contingency, South Africa, they argued, was particularly vulnerable. Various measures were taken to buttress the defence force, which had been stripped out for reasons of economic efficiency by the nationalist governments, and counter strategies to meet each of the three contingencies were designed and, by degree, implemented. These measures, sometimes meaningful, but often feeble, included increased professionalism in the military; appointments based upon military merit rather than political affiliation; the search for alliances; and re-equipment. With time three broad principles emerged. Firstly, the zone of deployment for the UDF was Africa and the UDF would only be deployed for the immediate defence of South Africa, where it would enjoy the advantages of technological asymmetry. Here was a further assumption: that the UDF would never again have to be deployed to Europe. ${ }^{74}$ Secondly, the UDF would be a small force, well-equipped for its purpose. There would be an emphasis on mounted infantry and a small air force, but little room for mechanisation as the lack of infrastructure in Africa pointed to little use for it. Thirdly, the UDF would nonetheless be sufficiently lethal to deal with internal conflict, sufficiently potent not to run the risk of many ownforce casualties. This is seen at Bulhoek, the Bondelswarts uprising, the Rand revolt of 1922, and the Ipumbu uprising of 1931, where the UDF, deployed in three of these cases to conduct punitive operations, had great psychological advantage.

The indifference and tendency toward isolation so manifest immediately after the war also declined in the following decades as the Nationalists grappled with the difficulty of having to marry ideology and reality. The 1930s brought several triggers for defence growth and a re-examination of defence policy. The first was the creation of the Fusion government in 1933 and the appointment of Oswald Pirow as defence minister. Second was the improving economy, that lead to Pirow's five year plans. The third was the Italian occupation of Abyssinia in 1936 and the sudden realisation that small advances would bring South Africa within airstriking range of Italian bases. Moreover, there were diplomatic moves by Germany to recover her lost colonies and, all the while, the Royal Navy was losing ground in the world naval ratings. The strategic landscape had changed suddenly; but the UDF, facing no immediate land-based threat, was designed to meet an enemy on African soil, somewhere near the equator, and in bush warfare. ${ }^{75}$

The lack of common vision regarding the threat perception, created substantial differences in the other strategic calculations. These considerations, as Millett has shown, regard the "anticipated theatres of operations, the immediacy in

74. After 1918, many South African political parties embraced the notion that South Africa should not become entangled in schemes for imperial defence; here Smuts and his shrinking support base, including the Unionists after 1921, were the exception. After the promulgation of the Statute of Westminster (1931) the NP in particular was adamant that South Africa was in no way bound to enter any war. Nationalists contended that a consistent policy of neutrality was South Africa's first line of defence against foreign aggression. See, J.S. Gericke Library, University of Stellenbosch: Dr D.F. Malan Collection 1/1/2355, "Die Agtergrond van ons Verdedigingsbeleid".

75. F.W. Perry, The Commonwealth Armies: Manpower and Organisation in Two World Wars (Manchester University Press, Manchester, 1990), pp 191-192. 
distance and time from the possible outbreak of war, the balance between deterring war or simply preparing to fight it, the likely length of a potential conflict, the role of allies", in South Africa's case, the role of the United Kingdom as primary "ally" and, of course, questions of force design and "the anticipated requirement for joint air-sea-land operations" ${ }^{76}$ Broadly-speaking, Africa south of the equator was considered by the government to be the zone of deployment for a small force that had to be sufficiently-lethal, psychologically-overwhelming, and well-equipped.

\section{Technology, military innovation and organisational politics}

It was difficult to imagine where such a force would come from, given the constraints facing the South African staff. As Captain (later Major General) Frank Theron noted in 1930 ,

the essence of the present-day problem ... is ... to take what is best and acceptable
to all in the traditional life and customs of the people, very gradually - for we are a
most conservative people - to evolve a system that will secure the State against all
internal trouble, and also raise the most formidable obstacle possible against foreign
aggression. ${ }^{77}$

Reformers, often in the face of a general staff and service organisations that did not always appreciate the potential of new forms of operations, managed to institutionalise new ideas on warfare. This was done through the institutionalisation of the study of military history and of the so-called "lessons" of the last war in the service schools and colleges, through the writing of doctrinal manuals, and through the creation of real operational units. South Africa too went through several processes to deduce "lessons", commencing during the $\operatorname{war}^{78}$ and following through a series of military publications produced in South Africa between 1920 and 1939. These included several drill manuals and textbooks ${ }^{79}$ as well as the official history of the Great War, which appeared in 1924. The last, described later by Agar-Hamilton as having "no outstanding merit", ${ }^{80}$ was a tremendous disappointment to Jack Collyer, a wartime chief of the general staff, who had hoped for a utilitarian history that would draw lessons and make instruction material. ${ }^{81}$ Collyer bridged the

76. A. Millett, "Patterns of Military Innovation in the Interwar Period", in Murray and Millett, Military Innovation in the Interwar Period, p 336.

77. Capt. F.H. Theron, "The Union Defence Forces of South Africa", Journal of the Royal United Service Institution, 75, 1930, pp 744-745.

78. SANDF Documentation Centre, Pretoria: WO1DA, Box 5, War Diary, South African Infantry Brigade Headquarters, Brig. Gen. H.T. Lukin to Maj. Gen. W. Furse, 3 August 1916, This has been quoted at length by lan Uys in his Rollcall; The Delville Wood Story (Uys Publishers, Johannesburg, 1991).

79. In 1921 "UDF Infantry Training, Part I (Drill) and Part II (Field Operations)"; "UDF Field Artillery Training"; "UDF Musketry Regulations"; a revision of "Mounted Riflemen Training"; "Tactical Notes for Officers"; and "Notes on Field Sanitation", were in the process of preparation.

80. J.A.I. Agar-Hamilton, "The Union of South Africa War Histories", in R. Higham (ed.), Official Histories; Essays and Bibliographies from around the World (Greenwood, Westport, 1970), p 443.

81. Collyer began his military career with the Cape Mounted Riflemen and saw action in the Second Anglo-Boer War as well as the two African campaigns of the First World War. He retired as Chief of the General Staff in 1920, when he embarked upon his histories of the South West and East African campaigns, which received official sanction in 1936. See I. van der Waag, "Contested Histories: Official History and the South African Military in the 20th 
gap himself with two textbooks, one on the German South West Africa campaign (1937) and another on the German East African campaign (1939). ${ }^{82}$

As far as Collyer was concerned European textbooks were irrelevant in Africa and he set about producing standard texts for warfare in Africa, deducing the "lessons" in the nineteenth-century utilitarian, didactic fashion, neatly set-out for the instruction of officers at the South African Military College. ${ }^{83}$ Although, many of his "lessons" were misinformed, they provide a rare insight into inter-war South African military thinking. Collyer, thought by some to be "the Liddell-Hart of South Africa" ${ }^{84}$ pointed out and quite rightly that South Africa had not been prepared for war in 1914 and his first call was for the systematic collection and updating of information in SubSaharan Africa and "the teaching of experience", emphasising both the importance of military history and the collection of accurate military information. Foreknowledge would lessen the difficulty in gaining strategic surprise, shorten campaigning in tropical Africa, and so limit casualties. However, Collyer, a mounted infantryman with fifty years of service in Africa, was clearly not a man for modern devices. He highlighted the problems of air power rather than possibilities ${ }^{85}$ and discounted the immediate value of mechanised transport in Africa, only mounted troops could be relied upon, and so provided unwittingly a theoretical basis for the "bush cart" policy of Oswald Pirow, who became defence minister in $1933 .^{86}$ The type of operations undertaken by South Africa in East Africa in 1940 and North Africa in 1941 had simply not been contemplated.

Britain acquiesced if not quite happily in the political drive by South Africa to take care of her own defences, leading to the closure of the imperial command in South Africa in 1921 and the establishment of a Seaward Defence Force in 1940. At times South African efforts had striking flair. For example, in late 1924, when the role of the Active Citizen Force was restricted to the combating of African and other uprisings within the Union, a special striking force designated the South African Field Force was organised under a single commander. Although small and having only a small mechanised nucleus, this force was revolutionary, predating Britain's experimental mechanised force by more than two years. ${ }^{87}$ The Field Force comprised two squadrons of the 1st Regiment, South African Mounted Riflemen and

Century", in J. Grey (ed.), The Last Word? Essays on Official History in the United States and British Commonwealth (Praeger, Westport, 2003), pp 27-52.

82. J.J. Collyer, The Campaign in German South West Africa, 1914-1915 (Government Printer, Pretoria 1937); and The South Africans with General Smuts in German East Africa, 1916 (Government Printer, Pretoria, 1939).

83. Preface in Collyer, The South Africans with General Smuts in German East Africa. See also D. Visser, British Influence on Military Training and Education in South Africa: The Case of the South African Military Academy and its Predecessors", South African Historical Journal, 46, May 2002, pp 63-82.

84. J.S.M. Simpson, South Africa Fights (Hodder \& Stoughton, London, 1941), p 91.

85. "So far as the enemy troops were concerned, aerial action did little damage and produced trifling information": Collyer, The South Africans with General Smuts in German East Africa, p 87.

86. Collyer, The South Africans with General Smuts in German East Africa, pp 266-277; as well as O. Pirow, James Barry Munnik Hertzog (Howard Timmins, Cape Town, n.d.), p 219; and P.E. von Lettow-Vorbeck, My Reminiscences of East Africa (Hurst \& Blackett, London, 1920), p 50.

87. Lord Carver, The Apostles of Mobility: The Theory and Practice of Armoured Warfare (Holmes \& Meier, New York, 1979), pp 38, 48. 
three batteries of the SA Field Artillery; ${ }^{88}$ with the 1 st Regiment SAMR reorganised to include an Armoured Car Section of two vehicles (imported from the UK in 1925), each with two machine guns. ${ }^{89}$ This special force could be dispatched at a moment's notice to any location within the country, to deal with disturbances in a quick and clinical manner. Yet, as events turned out, in the face of financial stringency and louder air voices, the Field Force was disbanded on 31 March $1926 .{ }^{90}$

There were a number of reasons for this. Airpower had a powerful voice in Sir Pierre van Ryneveld, who became CGS in 1933, and airpower seemed to provide a potent but cheap means of pacification. In 1922, the Bondelswarts rebellion had folded following the deployment of just two aircraft and, three years later, the Rehoboth rebellion was put down with the SAAF as the only portion of the UDF employed to assist the South West African administration. ${ }^{91}$

The development of a South African navy faced diverse institutional barriers and as a result, naval matters remained neglected through the 1920s and into the 1930s. ${ }^{92}$ Defence Headquarters (DHQ) was, after all, first dominated by the army and, after 1933, by an increasing number of airmen. British officials, who got to know their South African opposite numbers well, thought little of Van Ryneveld. Of him Evans, the British admiral, opined: "[he] knows and cares little about the Navy, but is a most enthusiastic airman. He will be only too ready to seize on any remark about mobility to press for an expansion of the Air Force to the exclusion of all else." Viewed from Simonstown, Major General Andries Brink, an erstwhile CGS and head of the commandos in 1939, was thought worse. He was, Evans thought, "no lover of England or of the Royal Navy, and he is very cautious where money is concerned. He may be expected to support any suggestion for doing as little as possible". ${ }^{3}$

In these quotations we see clearly three reasons for the neglect of defence and particularly of coastal defence: dominion nationalism, a focus on land and after 1933 on air forces, and the impact of the financial stringency of the 1930s. Moreover, Van Ryneveld and Brink, who clearly shared views on South African force size and force design, dominated the UDF during the 1930s. Their mainstreaming an embryo air force, at the cost of coastal defence and of naval

88. Abridged Annual Report of the Department of Defence for the Year ended 30 June 1925 (Government Printer, Pretoria, 1926), paragraph 10.

89. SANDF Documentation Centre, Pretoria: DC, Box 559, file DC 6/57205 O.C. Field Force Roberts Heights. Sadly very few documents dealing with the South African Field Force are to be found at the South African Military Archives in Pretoria because most of the records generated by the Commander of the S.A. Field Force were destroyed following an archival appraisal in 1933. See SANDF Documentation Centre, Pretoria: DC, Box 1910, file DC 251/6, Records Defence Department Destruction of Valueless Records.

90. Abridged Annual Report of the Department of Defence for the Year ended 30 June 1926 (Government Printer, Pretoria 1927), pp 12-17.

91. SANDF Documentation Centre, Pretoria: DC, Box 1026, file DF 573/9, Rehoboth Disturbances 1925, Circular DF 9/573, 21 April 1925.

92. This view was certainly held by the Admiralty at the time. See TNA: DO 35/186B/11, Report by Major A.N. Williams, R.M., former Royal Navy intelligence officer stationed in Cape Town, 17 April 1934.

93. TNA: DO 119/1052, Memorandum on South African Coast Defences, attached to Evans to High Commissioner, 10 September 1935. These opinions, while seemingly unkind, were widespread within British circles and were directed broadly at South African officialdom. See also UCT: BC81, Papers of Sir W.H. Clark, Ca1, Sir William Clark to Sir Edward Harding, 14 January 1935. 
forces, is clearly illustrated by the South African nominations (made since 1926) for courses in Britain. During this period army officers dominated with 17 courses of the total 29. Naval personnel had a brief flash in the early 1930s, when their numbers (4) equalled the army candidates during the years 1930-1932. However, after 1933 and the advent of the Fusion government and the appointments of Pirow as defence minister and of Van Ryneveld as CGS, the picture changed. Of the 13 positions filled from 1933 to 1938 , more than half were for Van Ryneveld's airmen. $^{94}$

There was, moreover, an official British perception that South Africans, and Oswald Pirow the defence minister from 1933, were reticent to spend money on the adequate but unspectacular. Pirow was thought to be

a man of action who likes the big thing and who has little use for half measures. Also,
he is a great lover and admirer of South Africa and would strongly resent any remark
which might be interpreted as belittling his country. In addition, he is very air-minded. ${ }^{95}$

Increasingly attention was focused and resources spent on the development of air power and land and naval matters were increasingly neglected. A redistribution of funds and opportunities from the army and naval service to the air force was the pattern for the remainder of the interwar period with several defence acquisitions contracted with Germany.

While a surprisingly good balance existed, throughout the period, between the two language groups (see Table 1), the political elites packed the structures with their supporters and, reading popular sentiment, few South Africans in 1914 and 1939 had full confidence in the skill and political neutrality of the bulk of the officer corps. In December 1914, the Archbishop of Cape Town dismissed Sir Duncan Mackenzie, who had led the field forces against Bambata in 1906, as brave but impetuous, and like the other South African commanders, an amateur and "no match for professional German officers". ${ }^{96}$ Military advice was not institutionalised and military professionalism was not always thought compatible with civilian control. At different times, changes were made to the high command in the form of appointments and purges - for political reasons. Purges took place on at least five occasions between 1914 and 1948, although on each occasion for unique reasons. South Africa entered the Second World War lacking broad-based national support. Discontent seethed, particularly in rural districts, ${ }^{97}$ and in the Transvaal several senior officers were charged with "conduct prejudicial to good order and military discipline". ${ }^{88}$

94. SANDF Documentation Centre, Pretoria, Annual Reports of the Department of Defence, 1925-1939.

95. TNA: DO 119/1052, Memorandum on South African Coast Defences, attached to Evans to High Commissioner, 10 September 1935.

96. Wits: Archbishop Carter Papers, William Carter to Algernon Lawley, 18 December 1914. Similar views filled the press: See SANDF Documentation Centre, Pretoria: DC, Box 573, file D.9199, European Crisis General, Volume 7, Editor of Transvaal Leader to Smuts, 7 January 1915.

97. NASAP: A1 Smuts Papers, Volume 132, Capt. D.J. Louw to Lt. Col. C.L. Engelbrecht, 1 November $1939 \mathrm{p} 11$.

98. NASAP: A1 Smuts Papers, Volume 132, Col B.W. Thwaites, Director of Intelligence to Military Secretary to the Prime Minister, 14 November 1939 (f.15). 
Moreover, the commanders and staff officers had no real knowledge of their duties in war. In a controversial book published in 1960, Eric Hartshorn, brigade major of the 1st SA Infantry Brigade Group and later commander of the 1st Transvaal Scottish, claimed that many of the troops had no confidence in "the majority of Senior Regular Officers" at DHQ. ${ }^{99}$ No senior general staff officers for divisions and brigades were named in peace. A careful and deliberate selection of the best men, not the politically-reliable, was therefore as vital in 1939 as it had been in 1914. Although the question of commands and staffs was all-important, the general staff was the chief difficulty. Whereas the general staff officer, as Collyer noted, should be a trained soldier and his training is a matter of years, a staff course for ACF officers lasted just one month. A staff course for Permanent Force officers - abandoned before the war - used to last from $3 \frac{1}{2}$ to 4 months and courses of this duration for the training of a general staff officer was thought by Collyer to be "almost [a] waste of time". 100

Some South African officers had received training at British institutions, like Camberley, Woolwich, Cranwell and Dartmouth. Yet, this too, had little impact. They were too few and many were subsequently seconded to the British forces. ${ }^{101}$ Nonetheless, there were exceptions. Dan Pienaar (1893-1942) had immense prestige and popularity with the rank and file; Harlech, the British high commissioner, thought far more of him than any other South African commander and this, characteristic of Boer traditions, he thought made the other South African generals jealous. ${ }^{102}$ George Brink (1889-1971), hero of the Abyssinian campaign and commander of the 1st Division at Alamein, had attended several arms courses in the United Kingdom and lectured gunnery, mapping and tactics at the Military College in the 1920s. A classmate of Bernard Montgomery, Bernard Paget and Richard O'Connor, he reckoned Camberley to have been of "inestimable value". Brink, his biographer tells us, "was assiduous in assimilating data on military organisation and administration. He continued to study on his own. To the end of his life his reading, apart from newspapers and periodicals, consisted largely of political and military history". 103

At the Military College he influenced the Permanent Force and Active Citizen Force officers, from whose ranks the Second World War leadership came. Under his guidance, junior officers studied the art of war at the tactical level, while senior officers deliberated on the command and logistics of larger formations. Commissioned by the pre-war defence minister, Oswald Pirow, Brink went on a study visit to Europe in 1937, when he studied the British armed forces, those of France and Italy, the potential enemies in Africa, and, above all, Germany. Brink

99. E.P. Hartshorn, Avenge Tobruk (Purnell, Johannesburg, 1960).

100. NASAP: A1 Smuts Papers, Volume 132. Statement of the Local Military Position on 7 September 1939 and steps taken thereafter.

101. Abridged Annual Report of the Department of Defence for the Year ended 30 June 1921 (Government Printer, Pretoria, 1922), p 4.

102. TNA: DO35/581/3, G9/21, Lord Harlech to Emrys Evans, 24 November 1942. See also A.M. Pollock, Pienaar van Alamein; Die Lewensgeskiedenis van 'n Groot Suid-Afrikaanse Soldaat (Cape Times, Kaapstad, 1943), pp 15-20.

103. C. Birkby, Uncle George: The Boer Boyhood, Letters and Battles of Lieutenant-General George Edwin Brink (Jonathan Ball, Johannesburg, 1987), pp 65-66. 
returned brimming with ideas to revitalise the Union Defence Force. ${ }^{104}$ His zeal and progressive spirit is impressive, particularly when seen against the gloomy background of the era. No wonder the critical Baston thought Brink "by far the ablest soldier at General Headquarters". 105

Yet the greatest hiatus was a broad lack of regimental experience, something which the perceptive Baston did not miss. He reported that the UDF would be let down by its junior officers, who, he thought, were poorly selected and as poorly trained. The selection boards, under the influence of defence secretary Broeksma and Colonel Hans van Rensburg, attached primary importance to the appointment of Afrikaners and particularly of Afrikaners with a rather anti-British background. ${ }^{106}$ At the same time, promising "British" material was often rejected due to the bilingualism requirement, which, he thought, "for one reason or another seemed to bear much more heavily on them than on the Afrikaner candidates". ${ }^{107}$ Moreover these young Afrikaner officers were thought to be avowed republicans, still permeated by the tradition of individualism, although not quite of the kind that imbued the leaders of the old Boer commandos. These youngsters, not exposed to the conditions that formed the old leaders, lacked self-control and experience. This was confirmed by Collyer. ${ }^{108}$

Doctrinal development did not keep pace with technological developments and the mechanisation of ground forces and the application of new technology contrasted sharply with developments in Europe. Although South Africa had the industrial capacity for the development of armour and mechanised forces, arguments based upon the nature of potential enemy forces, poor infrastructure and terrain inaccessibility combined with government policy and financial stringency resulted in little being done. Southern Africa, the focus of South African defence policy, was also thought to be unfavourable for mechanised warfare. Inadequate roads and multifarious geographic features concentrated energy on the development of the air arm for operations in Africa and a system of coastal defences to repel a sea assault, as well as a mix of British and Boer-type infantry supported by field artillery. As a result, an expeditionary force had to be prepared from scratch after September 1939 and the first South Africans to serve in the Second World War only left the country in July 1940. Yet the close relationship between the projected role of the Union Defence Force and the low priority given to force maintenance and weapons acquisition has been perceived by few writers.

In essence, Smuts' generals on the eve of the Second World War had little education, almost no training, and no experience. Moreover, there was an overemphasis on management, essentially the good execution of clerical and desk

104. Birkby, Uncle George, pp 71-72, 87-91. On military education in South Africa during this period see the insightful piece by Visser, "British Influence on Military Training and Education in South Africa", pp 63-82.

105. TNA: DO 35/1008/7, WG 429/13, as quoted in Clutterbuck to Stephenson, 29 September 1939.

106. Hans van Rensburg led the Ossewa-Brandwag, a right-wing, fascist-like, Afrikaner movement established in 1938 and suppressed by the Smuts government during the Second World War.

107. TNA: DO 35/1008/7, WG 429/13, Clutterbuck to Stephenson, 29 September 1939.

108. NASAP: A1 Smuts Papers, Volume 132, f 66, Memorandum by Maj. Gen. Jack Collyer, c.1939. 
tasks, together with an over focus on language parity and English-Afrikaans equity brought considerable military regression. The transition from a colonial army to a modern defence force was therefore not easy, although the South African government did make limited post-1918 attempts to adapt to the radically-changed face of modern warfare. However, unable to compete militarily with major powers, technology was harnessed to make pacification more economic and, for the rest, the nationalist governments of the interwar period hoped to remain neutral in terms of future global conflict. Nonetheless, the South African staff considered a major campaign in Africa, probably near the equator, a distinct possibility and trained and planned accordingly. ${ }^{109}$

\section{Conclusion}

South Africa experienced three total wars during the first half of the twentieth century, which makes her unique. Moreover, through this sequence - the Second Anglo-Boer War, the First World War and the Second World War - the totality reduced progressively and it was a limited war, a flashpoint of the Cold War, fought at the century's end that changed the country irrevocably.

Nonetheless, the period 1900-1940 witnessed important developments in South African military policy. The first of these was structural, involving the departure of British armed forces and a decisive shift to a South African monopoly of military force within her borders and the consolidation of her apparatus in permanent land, air, and sea forces, along with the bureaucratic infrastructure necessary to sustain them. This changed both the nature of the defence structure and of the conduct of war on the subcontinent itself. Inter-state conflict became more distant, while internal conflict became more prevalent, certainly during the middle of the period. The Union Defence Force faced outwards against external dangers to the colonial state, while internal threats were met by a variety of more peaceful tactics, which were well-developed by the second decade of the twentieth century.

The political debate for much of this period focused on the distribution of the burdens of defence, both across an increasingly-moribund British Empire and within the Union of South Africa, where "neutrality" was a rallying call for appeasers and pacifists, ever more militant Afrikaner nationalists and indeed anybody who bore a grudge against "the British". Such extraneous influences together with a mix of institutional factors brought military and intellectual regression between 1918 and 1939, although indeed the UDF through this period had the appearance of greater professionalism and assumed an internal organisation and forms of behaviour typical of Western counterparts. Yet, like the rest of the British Commonwealth, much of the doctrine and tactical innovation had not kept pace with technological developments. Training and training facilities were inadequate and there was a shortage of uniforms and equipment. The army, despite constant undermining by the Afrikaner nationalist press, was still an honoured and respectable profession. Promising commanders studied tactics and strategy at the SA Military School, and the cream went on to British institutions, in some cases not to return. This continued until the final fall of Smuts in 1948 and the

109. Cowie, "Union of South Africa", pp 262-263. Dr Andrew Stewart kindly furnished this reference. 
establishment of more specialised institutions of military education and training in South Africa. By 1945 the UDF displayed state-of-the-art tactics and operational originality. They had moved from an emphasis on mounted infantry in 1912 to the combined operations so characteristic of the Second World War.

\begin{abstract}
Based largely on a study of official archives and private papers held in South Africa and the United Kingdom, this article sketches the political-strategic landscape on which the armed forces of South Africa operated between 1900 and 1940 and analyses the organisational and extraneous factors that affected their functioning and influenced their preparation during peacetime. It explores the doctrinal framework, including an assessment of the services' commitment to the problem of doctrine and of their rigour in drawing, learning and implementing the so-called "lessons" of the First World War. The South African reaction to the "total war' experience of industrialised warfare is discussed and the attempts, apparently always feeble, by the South African state to adapt to the changing face of modern warfare are explained. It comes with little surprise that the Union Defence Force, after the experiences of the Western Front (1916-1918), was still so unprepared for European warfare in 1941.
\end{abstract}

Keywords: Union Defence Force, First World War, Second World War, defence policy, JC Smuts

\title{
Opsomming
}

Hierdiedie artikel is gebaseer op primêre navorsing uit amptelike argiewe en privaat versamelings in beide die Verenigde Koninkryk en Suid-Afrika, en skets die politiesstrategiese landskap waarin die Suid Afrikaanse verdedigingsmagte ontplooi het tussen 1900 en 1940. Verder bied die artikel 'n analise van die samestelling van die Unieverdedigingsmag, hul unieke organisasie en ander faktore wat 'n uitwerking gehad het op die verdedigingsmag se voorbereiding gedurende vredestydperke. Die sogenaamde 'lesse' wat geleer is tydensd Suid-Afrika se deelname aan die Eerste Wêreldoorlog, sowel as die gewilligheid om dié lesse in amptelike doktrine te implementeer, word ondersoek. Die Suid-Afrikaanse begrip van 'totale oorlogvoering', en Suid-Afrika se eerste ervaring van oorlogvoering op 'n industriële skaal word ook bespreek. Die halfhartige manier waarop die Suid-Afrikaanse staat aangepas het by moderne oorlogvoering gedurende dié typerk word ook bespreek. Dus is dit geen wonder dat die Unieverdedigingsmag gedurende 1941, veral na die ervaringe op die Westelike Front (1916-1918), steeds grootendeels onvoorbereid was vir Europese oorlogvoering nie.

Sleutelwoorde: Unieverdedigingsmag, Eerste Wêreldoorlog, Tweede Wêreldoorlog, verdedigingsbeleid, JC Smuts 